\title{
THE EFFECT OF CHLORIDE CONTENT IN WATER ON THE TOXICITY OF SODIUM NITRITE FOR SPINY-CHEEK CRAYFISH (ORCONECTES LIMOSUS RAF.)
}

\author{
P. KOZÁK, J. MÁCHOVÁ, T. POLICAR
}

University of South Bohemia České Budějovice, Research institute of Fish Culture and Hydrobiology at Vodňany, Zátiší 728/II, 38925 Vodňany, Czech Republic.

E-Mail: kozak@vurh.jcu.cz

Reçu le 19 octobre 2004

Accepté le 12 avril 2005

Received October 19, 2004

Accepted April 12, 2005

\begin{abstract}
Toxicity of sodium nitrite for the spiny-cheek crayfish (Orconectes limosus) was assessed in relation to the concentration of chlorides diluted in water. Results of the tests confirmed a favourable effect of chloride content in water on the tolerance of spiny-cheek crayfish to nitrites. The $96 \mathrm{hLC}_{50}$ value of $4.8 \mathrm{mg} \mathrm{l}^{-1}, 17.7 \mathrm{mg} \mathrm{l}^{-1}, 34.7 \mathrm{mg} \mathrm{l}^{-1}, 50.5 \mathrm{mg} \mathrm{l}^{-1}$, $74.4 \mathrm{mg} \mathrm{l}^{-1}$, and $96.6 \mathrm{mg} \mathrm{l}^{-1} \mathrm{~N}-\mathrm{NO}_{2}{ }^{-}$found out in individual tests corresponded, respectively to a chloride content of $11,40,100,200,300$ and $400 \mathrm{mg} \mathrm{l}^{-1} \mathrm{Cl}^{-}$in diluting water. Linear relationship of the $96 \mathrm{hLC}_{50}$ values on chloride concentration $(y=0.23 x+7)$ was proven statistically $(R=0.995)$.
\end{abstract}

Key-words: nitrite, crayfish, chlorides, water quality, toxicity test.

\section{EFFET DE LA CONCENTRATION EN CHLORIDES DE L'EAU SUR LA TOXICITE DU NITRITE DE SODIUM POUR L'ECREVISSE AMÉRICAINE (ORCONECTES LIMOSUS RAF.)}

\section{RÉSUMÉ}

La toxicité du nitrite de sodium vis-à-vis de l'écrevisse américaine (Orconectes limosus) a été évaluée en relation avec la concentration des chlorides dilués dans l'eau. Les résultats des expériences ont confirmé l'effet favorable de la concentration des chlorides dans l'eau sur la tolérance des écrevisses américaines envers les nitrites. Les valeurs du $96 \mathrm{hLC}_{50}$ de $4,8 \mathrm{mg} \mathrm{l}^{-1}, 17,7 \mathrm{mg} \mathrm{l}^{-1}, 34,7 \mathrm{mg} \mathrm{l}^{-1}, 50,5 \mathrm{mg} \mathrm{l}^{-1}, 74,4 \mathrm{mg} \mathrm{l}^{-1}$, et $96,6 \mathrm{mg} \mathrm{l}^{-1}$ de N-NO${ }_{2}^{-}$trouvées dans les expériences correspondent respectivement à une teneur de l'eau en chlorides de 11, 40,100, 200, 300 et $400 \mathrm{mg} \mathrm{l}^{-1} \mathrm{Cl}^{-}$. Une relation linéaire entre les valeurs du $96 \mathrm{hLC}_{50}$ et les concentrations en chlorides de l'eau $(\mathrm{y}=0.23 \times+7) \mathrm{a}$ été prouvée statistiquement $(R=0,995)$.

Mots-clés : nitrates, écrevisses, chlorides, qualité de l'eau, test de toxicité.

\section{INTRODUCTION}

Nitrite $\left({\mathrm{N}-\mathrm{NO}_{2}}^{-}\right)$is an intermediate product in the oxidation of ammonia. Nitrite is usually found together with nitrate and ammonia in water. It usually occurs in small concentration considering its chemical and biochemical instability. In aquatic ecosystem, 
nitrite concentrations are elevated by pollution with nitrogenous wastes and imbalances in bacterial nitrification and denitrification processes. Nitrite is transformed by nitrification to nitrate under aerobic condition. The average concentration of $\mathrm{N}^{-\mathrm{NO}_{2}}{ }^{-}$in ground water ranges from 0.004-0.179 $\mathrm{mg} \mathrm{l}^{-1}$. Higher concentrations (more than $1 \mathrm{mg} \mathrm{l}^{-1}$ ) occur in wastewater (PITTER, 1999) and could increase also in intensive aquaculture and recirculation systems usually in starting filters. The nitrification process is used to decrease ammonia concentration that is the main product of fish metabolism (SVOBODOVÁ et al., 2003). In fish, nitrite is absorbed at the gills and oxidizes the iron in the haemoglobin molecule to methemoglobin. The result of nitrite poisoning is hypoxia caused by a reduction in the blood's oxygen carrying ability. It is likely that the same type of reaction that occurs with the iron of haemoglobin also occurs with the copper in crustacean hemocyanin (COLT and ARMSTRONG, 1981)

Freshwater fish and crustaceans are hyperosmotic to their environment. They actively take in ions via the gills to balance that lost in their urine and the passive outflow by gills. Nitrite has an affinity for the active chloride uptake mechanism by chloride cells in the gills (MAETZ, 1971). Chloride cells excrete ammonia or $\mathrm{H}^{+}$ions for $\mathrm{Na}^{+}$ions and bicarbonate $\left(\mathrm{HCO}_{3}^{-}\right)$for $\mathrm{Cl}^{-}$ions (LOVE, 1980). $\mathrm{NO}_{2}^{-}$has affinity to $\mathrm{Cl}^{-} / \mathrm{HCO}_{3}^{-}$exchanging. Part of $\mathrm{Cl}^{-}$demand is replaced by $\mathrm{NO}_{2}^{-}$when it is in water. Fish with higher speed of chloride uptake by gills (rainbow trout, perch, pike) are more sensitive to nitrites then fish with lower speed of chloride uptake (eel, common carp, tench) (WILLIAMS and EDDY, 1986). The competition between chloride and nitrite ions transport across the gill membrane explains because the higher concentration of $\mathrm{Cl}^{-}$protects fish against toxic impact of nitrite (JENSEN, 2003). The positive effect of chloride for fish tolerance to nitrites has been demonstrated in other studies in fish (SVOBODOVÁ et al., 1987; HILMY, 1987; ATWOOD et al., 2001; HUERTAS et al., 2002; TAVARES and BOYD, 2003; FULLER et al., 2003) and for crayfish (JEBERG and JENSEN, 1994; BEITINGER and HUEY, 1981). CRAWFORD and ALLEN (1977) showed that toxicity of nitrite depended on water salinity. In seawater, 50-100 times lower mortality was observed than in fresh water in same concentration of nitrite. The relationship between nitrite toxicity and chloride concentration is linear (RUSSO and THURSTON, 1977). The effect of nitrite on chloride regulation in Pacifastacus leniusculus was studied by HARRIS and COLEY (1991).

Other anions also have a positive impact on decreasing nitrite toxicity, mainly bromide (EDDY et al., 1983). Carbonate and nitrate also have a significant impact but they are not as effective as chloride and bromide (LEWIS and MORRIS, 1986).

The $96 \mathrm{hLC}_{50}$ value for nitrite in freshwater fish ranges from 0.66 to $200 \mathrm{mg} \mathrm{l}^{-1}$, while values for crustaceans range from 8.5 to $15.4 \mathrm{mg} \mathrm{l}^{-1}$ (BOYD, 1990 in ROUSE, KASTNER and REDDY, 1995). Only WICKINS (1976) mentioned a high tolerance to nitrite in prawns $\left(48 \mathrm{hLC}_{50}=170 \mathrm{mg} \mathrm{l}^{-1} \mathrm{~N}-\mathrm{NO}_{2}^{-}\right)$. ROUSE, KASTNER and REDDY (1995) found the $96 \mathrm{hLC}_{50}$ values for nitrite in hatching redclaw crayfish, Cherax quadricarinatus of $1.03 \mathrm{mg} \mathrm{l}^{-1}\left(24 \mathrm{hLC}_{50}=1.4,48 \mathrm{hLC}_{50}=1.1,72 \mathrm{hLC}_{50}=1.1 \mathrm{mg} \mathrm{l}^{-1}\right)$. HYMEL (1985) in ROUSE, KASTNER and REDDY (1995) reported that the $96 \mathrm{hLC}_{50}$ value for nitrite toxicity to juvenile Procambarus clarkii was $5.94 \mathrm{mg} \mathrm{l}^{-1}$, LIU et al. (1995) reported a $4.7 \mathrm{mg} \mathrm{l}^{-1}$ nitrite toxicity to juvenile redclaw and POLICAR et al. (2003) reported a $48 \mathrm{hLC}_{50}$ value for one year old noble crayfish of $6.7-33.3 \mathrm{mg} \mathrm{l}^{-1} \mathrm{NO}_{2}^{-}$. These higher values could be related to age and bigger size of these species (ROUSE, KASTNER and REDDY, 1995). MALONE and BURDEN (1988) in ROUSE, KASTNER and REDDY (1995) recommended maintaining nitrite levels below $0.5 \mathrm{mg} \mathrm{l}^{-1}$ in recirculation systems used for holding adult $P$. clarkii.

Low levels of nitrite could produce sub lethal effects where the fitness of the species might be reduced because of either ionic imbalance of extra cellular fluids or increased energy costs of maintaining additional transport sites (HARRIS and COLEY, 1991). No mortality was observed in redclaw crayfish in $10 \mathrm{mg} \mathrm{l}^{-1} \mathrm{NO}_{2}^{-}\left(24 \mathrm{hLC}_{50}=42.9 \mathrm{mg} \mathrm{l}^{-1}\right.$ $\left.\mathrm{NO}_{2}^{-}, \quad 48 \mathrm{hLC}_{50}=37.1 \mathrm{mg} \mathrm{l}^{-1} \mathrm{NO}_{2}^{-}, \quad 96 \mathrm{hLC}_{50}=25.9 \mathrm{mg} \mathrm{l}^{-1} \mathrm{NO}_{2}^{-}\right)$(MEADE and WATTS, 
1995). ROUSE, KASTNER and REDDY (1995) presented that 24 hours exposure to nitrite concentrations of $0.4 \mathrm{mg} \mathrm{l}^{-1} \mathrm{NO}_{2}^{-}$and $0.6 \mathrm{mg} \mathrm{l}^{-1} \mathrm{NO}_{2}^{-}$decreased subsequent growth of redclaw crayfish by $17 \%$ and $67 \%$ and increased mortality by $5 \%$ and $48 \%$, respectively.

The aim of this study was to examine acute toxicity of nitrite in spiny-cheek crayfish and to verify the positive effect of chloride on increasing crayfish tolerance to higher concentrations of nitrite in water.

\section{MATERIAL AND METHODS}

The methodology of acute toxicity test in fish (ČSN EN ISO 7346-1) was carried out for acute toxicity tests. One-year-old spiny-cheek crayfish of $38.7 \pm 5.3 \mathrm{~mm}(27-55 \mathrm{~mm})$ of total body length, $11.9 \pm 1.8 \mathrm{~mm}(7-18 \mathrm{~mm})$ of carapace length and $1.6 \pm 0.7 \mathrm{~g}(0.45$ $4.75 \mathrm{~g}$ ) of body weigh were collected from Kořensko dam (Vltava river).

Altogether, six toxicological tests with various chloride concentrations in water were performed. One of them was without chloride addition (content of chlorides in diluting water $=11 \mathrm{mg} \mathrm{l}^{-1} \mathrm{Cl}^{-}$). The others were with added chloride concentration in water (final concentrations $=40,100,200,300,400 \mathrm{mg} \mathrm{l}^{-1} \mathrm{Cl}^{-}$). Two day-old aerated drinking water (pH 7.2, ANC (acid neutralizing capacity) $0.5 \mathrm{mmol} \mathrm{I}^{-1}, \mathrm{COD}_{\mathrm{Mn}}$ (permanganate index) $2.2 \mathrm{mg} \mathrm{l}^{-1}, \Sigma \mathrm{Ca}^{2+}+\mathrm{Mg}^{2+} 14.0-15.0 \mathrm{mmol}^{-1}, \mathrm{~N}-\mathrm{NH}_{4}{ }^{+} 0.03 \mathrm{mg} \mathrm{l}^{-1}, \mathrm{~N}-\mathrm{NO}_{3}^{-} 5.2 \mathrm{mg} \mathrm{l}^{-1}, \mathrm{~N}-$ $\mathrm{NO}_{2}^{-} \leq 0.01 \mathrm{mg} \mathrm{l}^{-1}, \mathrm{Cl}^{-11.0} \mathrm{mg} \mathrm{l}^{-1}, \mathrm{SO}_{4}{ }^{2-} 51.5 \mathrm{mg}^{-1}, \mathrm{P}_{-} \mathrm{PO}_{4}{ }^{3-} \leq 0.01 \mathrm{mg} \mathrm{l}^{-1}$ ) was used as a diluting water.

Sodium nitrite $\left(\mathrm{NaNO}_{2}\right)$ was used as the toxicant for the nitrite bioassay. Test concentrations for nitrites were:

- 2.0, 4.1, 10.1, 20.3, 41.6, $60.9 \mathrm{mg} \mathrm{l}^{-1} \mathrm{~N}^{-\mathrm{NO}_{2}}{ }^{-}$at 11,40 and $100 \mathrm{mg} \mathrm{l}^{-1} \mathrm{Cl}^{-}$;

- $20.3,40.6,60.9,81.2,101.0,121.7 \mathrm{mg} \mathrm{l}^{-1} \mathrm{~N}^{-N_{2}}{ }^{-}$at 200 and $300 \mathrm{mg} \mathrm{l}^{-1} \mathrm{Cl}^{-}$;

- $20.3,40.6,60.9,81.2,101.0,121.7,142.0$ and $162.3 \mathrm{mg} \mathrm{l}^{-1} \mathrm{~N}^{-N_{2}}{ }_{2}^{-}$at $400 \mathrm{mg} \mathrm{l}^{-1} \mathrm{Cl}^{-}$

Chloride was dosed as a $\mathrm{NaCl}$.

Totally, 1100 crayfish were used for the experiment ( 25 crayfish were used for each chloride and nitrite concentration). The crayfish were stocked to 25-litre aquarium filled with 15 litres of water. Water was not exchange. Plastic spirals were provided as shelters to minimize cannibalism. Crayfish were stocked in the diluting water without the substance being tested.

Exposure time was 96 hours. Crayfish were not fed during the test. Crayfish mortality, oxygen content, $\mathrm{pH}$ value and temperature were observed 1 hour after stocking and then daily.

Water $\mathrm{pH}$ value was not adjusted and ranged from 7.05 to 7.84 . Temperature during the test ranged from $17^{\circ} \mathrm{C}$ to $19^{\circ} \mathrm{C}$, and the oxygen saturation was more than $80 \%$.

Values of $96 \mathrm{hLC}_{0}, 96 \mathrm{hLC}_{50}, 96 \mathrm{hLC}_{100}$ nitrite toxicity were calculated by probits analysis using software EKOTOX v 5.1 (INGEO Liberec CZ). The $96 \mathrm{hLC}_{50}$ value was statistically evaluated by regression analyses using Microsoft Excel.

\section{RESULTS}

\section{Nitrite toxicity test in diluting water}

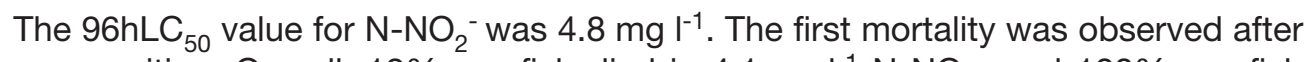
24-hour exposition. Overall, $12 \%$ crayfish died in $4.1 \mathrm{mg} \mathrm{l}^{-1} \mathrm{~N}-\mathrm{NO}_{2}-$ and $100 \%$ crayfish died in $60.9 \mathrm{mg} \mathrm{l}^{-1} \mathrm{~N}-\mathrm{NO}_{2}{ }^{-}$. Massive crayfish mortality was observed also in concentration of $10.1,20.3$ and $40.6 \mathrm{mg} \mathrm{l}^{-1} \mathrm{~N}-\mathrm{NO}_{2}^{-}$with total mortality after the next 24 hours. No 
mortality or behavioural changes were observed in the control group and in a $\mathrm{N}^{-\mathrm{NO}_{2}{ }^{-}}$ concentration of $2.0 \mathrm{mg} \mathrm{l}^{-}$(Table I).

\section{Table I}

Acute nitrite toxicity (cumulative mortality) for 0 . limosus related to time of exposure in a chloride concentration of $11 \mathrm{mg} \mathrm{l}^{-1} \mathrm{Cl}^{-}$(diluting water).

\section{Tableau I}

Toxicité aiguë des nitrites (mortalité cumulative) pour 0 . limosus en relation avec l'exposition à une concentration en chlorides de $11 \mathrm{mg} \mathrm{l-1} \mathrm{Cl-} \mathrm{dilués} \mathrm{dans} \mathrm{l'eau.}$

\begin{tabular}{|c|c|c|c|c|c|}
\hline \multirow{3}{*}{$\begin{array}{c}\text { Concentration } \\
\text { of } \mathrm{N}-\mathrm{NO}_{2}^{-}\left(\mathrm{mg} \mathrm{l}^{-1}\right)\end{array}$} & \multicolumn{5}{|c|}{ Cumulative mortality (\%) } \\
\hline & \multicolumn{5}{|c|}{ Time of exposition } \\
\hline & 1 hour & 24 hours & 48 hours & 72 hours & 96 hours \\
\hline 0.0 (control group) & 0 & 0 & 0 & 0 & 0 \\
\hline 2.0 & 0 & 0 & 0 & 0 & 0 \\
\hline 4.1 & 0 & 12 & 12 & 12 & 12 \\
\hline 10.1 & 0 & 72 & 100 & 100 & 100 \\
\hline 20.3 & 0 & 84 & 100 & 100 & 100 \\
\hline 40.6 & 0 & 96 & 100 & 100 & 100 \\
\hline 60.9 & 0 & 100 & 100 & 100 & 100 \\
\hline
\end{tabular}

\section{Toxicity test with higher level of chloride in diluting water} in Table II.

The results of acute toxicity tests at the variable $\mathrm{Cl}^{-}$concentrations are summarised

The Figure 1 show that higher concentrations of chlorides in water markedly increased crayfish tolerance to nitrite.

While a N-NO${ }_{2}^{-}$concentration of $10.1 \mathrm{mg} \mathrm{l}^{-1}$ with $11 \mathrm{mg} \mathrm{l}^{-1}$ of chloride induced $100 \%$ mortality after 24 hours, the same nitrite concentration with $40 \mathrm{mg} \mathrm{l}^{-1}$ of chloride did not induce any mortality after 96 hours exposition.

No mortality was observed in $400 \mathrm{mg} \mathrm{l}^{-1}$ of $\mathrm{Cl}^{-}$in $60.9 \mathrm{mg} \mathrm{l}^{-1}$ of $\mathrm{N}^{-\mathrm{NO}_{2}}{ }_{2}^{-}$concentration after 96 hours exposition (Figure 1).

The $96 \mathrm{hLC}_{50}$ value of $4.8 \mathrm{mg} \mathrm{l}^{-1}, 17.7 \mathrm{mg} \mathrm{l}^{-1}, 34.7 \mathrm{mg} \mathrm{l}^{-1}, 50.5 \mathrm{mg} \mathrm{l}^{-1}, 74.4 \mathrm{mg} \mathrm{l}^{-1}$, and $96.6 \mathrm{mg} \mathrm{l}^{-1} \mathrm{~N}-\mathrm{NO}_{2}^{-}$found out in individual tests corresponded, respectively to a chloride content of $11,40,100,200,300$ and $400 \mathrm{mg} \mathrm{l}^{-1} \mathrm{Cl}^{-}$in diluting water (Table III).

Linear dependence was found for $96 \mathrm{hLC}_{50}$ of sodium nitrite in various chloride concentrations (Figure 2).

The regression equation was calculated as:

$$
y=0.23 \times+7
$$

with

$\mathrm{x}=$ chloride concentration in diluted water $\left(\mathrm{mg} \mathrm{l}^{-1} \mathrm{Cl}^{-}\right)$,

$\mathrm{y}=96 \mathrm{hLC}_{50}$ value $\left(\mathrm{mg} \mathrm{l}^{-1} \mathrm{~N}-\mathrm{NO}_{2}^{-}\right)$.

The $96 \mathrm{hLC}_{0}$ and the $96 \mathrm{hLC}_{100}$ values increased similarly as the $96 \mathrm{hLC}_{50}$ value relate to chloride concentration. 


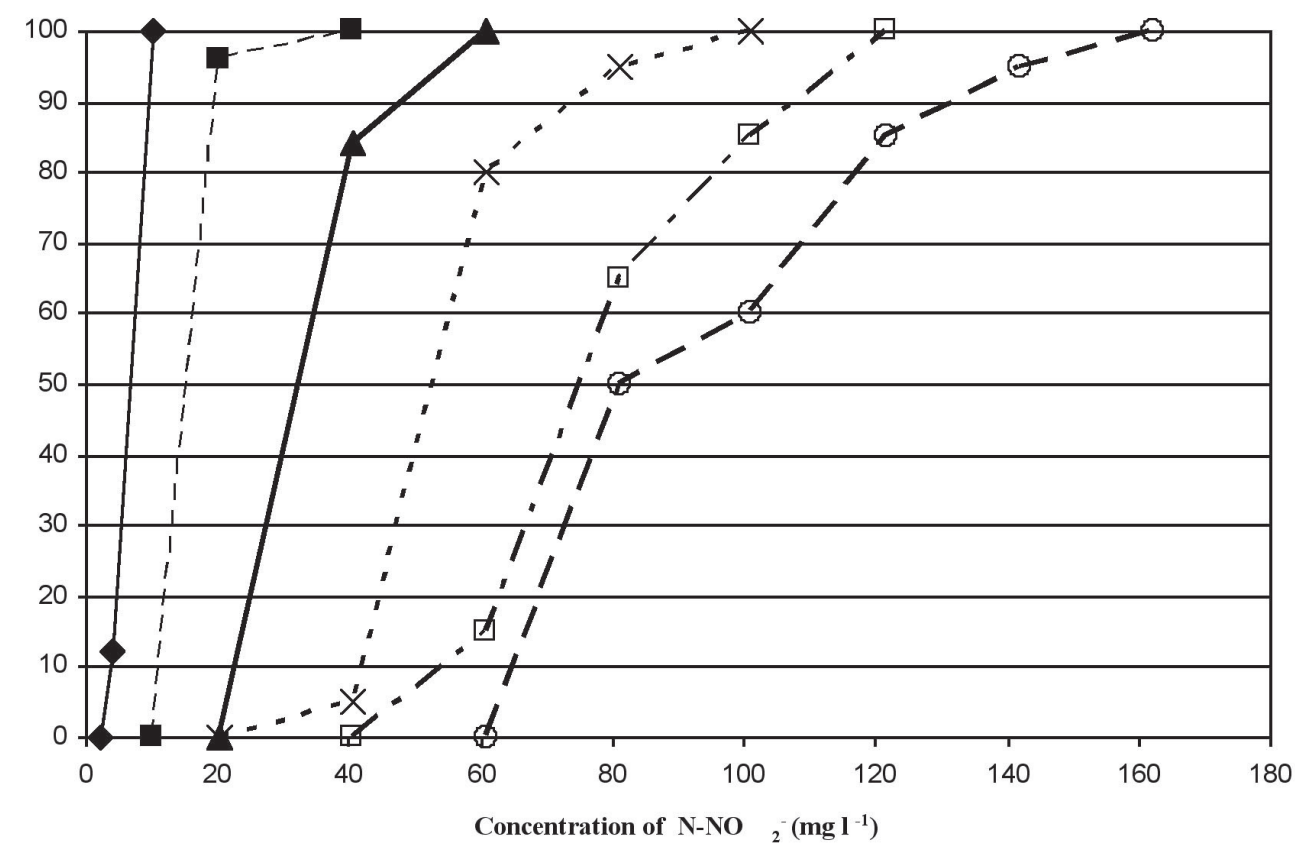

$10 \mathrm{mg} / \mathrm{l}-\rightarrow-40 \mathrm{mg} / \mathrm{l}$

$-100 \mathrm{mg} / \mathrm{l}=-\times-200 \mathrm{mg} / \mathrm{l}-\mathrm{-}-300 \mathrm{mg} / \mathrm{l}-\mathrm{-}-40$

$400 \mathrm{mg} / \mathrm{l} \mathrm{chlorides}$

Figure 1

Impact of chlorides to toxicity of nitrites for O. limosus. (96-h exposure).

Figure 1

Effet de la toxicité des nitrites sur O.limosus (96 h d'exposition).

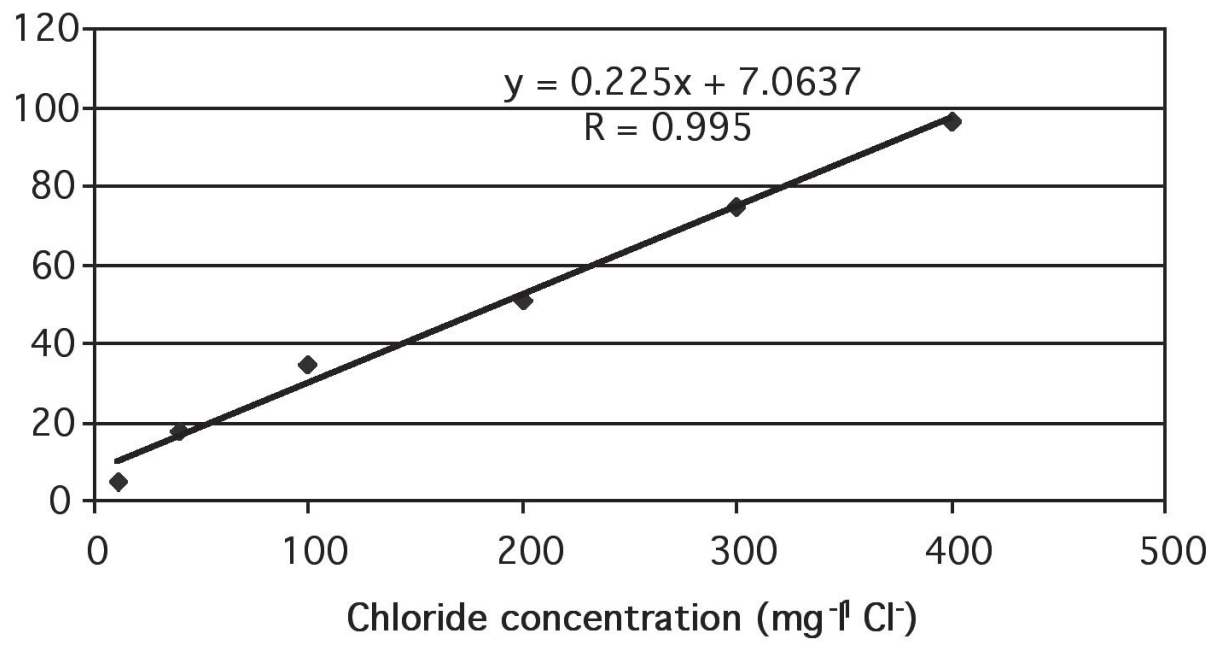

Figure 2

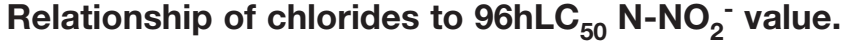

Figure 2

Effet des chlorides sur la valeur de $96 \mathrm{hLC}_{50} \mathrm{~N}-\mathrm{NO}_{2}{ }^{-}$. 
Table II

Impact of chlorides to toxicity of nitrites for O. limosus. (96-h exposure).

Tableau II

Effet de la toxicité des nitrites sur 0 . limosus (96 h d'exposition).

\begin{tabular}{|c|c|c|c|c|c|c|}
\hline \multirow{2}{*}{$\begin{array}{c}\text { N-NO } \\
\text { ( } \mathbf{m g ~ l}^{-1} \text { ) }\end{array}$} & \multicolumn{6}{|c|}{$\mathrm{Cl}^{-}$concentration (mg l-1) } \\
\cline { 2 - 7 } & $\mathbf{1 1 . 0}$ & $\mathbf{4 0 . 0}$ & $\mathbf{1 0 0 . 0}$ & $\mathbf{2 0 0 . 0}$ & $\mathbf{3 0 0 . 0}$ & $\mathbf{4 0 0 . 0}$ \\
\hline $\mathbf{0 . 0}$ (control group) & $0 \%$ & $0 \%$ & $0 \%$ & $0 \%$ & $0 \%$ & $0 \%$ \\
\hline $\mathbf{2 . 0}$ & $0 \%$ & $0 \%$ & $0 \%$ & - & - & - \\
\hline $\mathbf{4 . 1}$ & $12 \%$ & $0 \%$ & $0 \%$ & - & - & - \\
\hline $\mathbf{1 0 . 1}$ & $100 \%$ & $0 \%$ & $0 \%$ & - & - & - \\
\hline $\mathbf{2 0 . 3}$ & $100 \%$ & $96 \%$ & $0 \%$ & $0 \%$ & $0 \%$ & $0 \%$ \\
\hline $\mathbf{4 0 . 6}$ & $100 \%$ & $100 \%$ & $84 \%$ & $5 \%$ & $0 \%$ & $0 \%$ \\
\hline $\mathbf{6 0 . 9}$ & $100 \%$ & $100 \%$ & $100 \%$ & $80 \%$ & $15 \%$ & $0 \%$ \\
\hline $\mathbf{8 1 . 2}$ & - & - & - & $95 \%$ & $65 \%$ & $50 \%$ \\
\hline $\mathbf{1 0 1 . 0}$ & - & - & - & $100 \%$ & $85 \%$ & $60 \%$ \\
\hline $\mathbf{1 2 1 . 7}$ & - & - & - & $100 \%$ & $100 \%$ & $85 \%$ \\
\hline $\mathbf{1 4 2 . 0}$ & - & - & - & - & - & $95 \%$ \\
\hline $\mathbf{1 6 2 . 3}$ & - & - & - & - & - & $100 \%$ \\
\hline
\end{tabular}

\section{Table III}

Acute nitrite toxicity ( $L C_{0}, L_{50}$ and $L C_{100}$ values) for $O$. limosus related to chloride concentrations.

Tableau III

Toxicité des nitrites $\left(\mathbf{L C}_{0}, \mathbf{L C}_{50}\right.$ and $\mathbf{L C}_{100}$ values) pour $O$. limosus en relation avec la concentration en chloride.

\begin{tabular}{|c|c|c|c|}
\hline $\begin{array}{l}\text { Chloride concentration } \\
\qquad\left(\mathrm{mg} \mathrm{l}^{-1} \mathrm{Cl}^{-}\right)\end{array}$ & $\begin{array}{c}96 \mathrm{hLC}_{0} \\
\left(\mathrm{mg} \mathrm{l}^{-1} \mathrm{~N}-\mathrm{NO}_{2}^{-}\right)\end{array}$ & $\begin{array}{c}96 \mathrm{hLC}_{50} \\
\left(\mathrm{mg} \mathrm{l}^{-1} \mathrm{~N}-\mathrm{NO}_{2}^{-}\right)\end{array}$ & $\begin{array}{c}96 \mathrm{hLC}_{100} \\
\left(\mathrm{mg} \mathrm{l}^{-1} \mathrm{~N}-\mathrm{NO}_{2}^{-}\right)\end{array}$ \\
\hline 11 & 2.2 & 4.8 & 10.7 \\
\hline 40 & 8.9 & 17.7 & 35.5 \\
\hline 100 & 20.1 & 34.7 & 59.9 \\
\hline 200 & 22.8 & 50.5 & 112.1 \\
\hline 300 & 41.4 & 74.4 & 133.7 \\
\hline 400 & 55.05 & 96.6 & 169.5 \\
\hline
\end{tabular}




\section{DISCUSSION}

The $96 \mathrm{hLC}_{50}$ value for nitrite in one-year-old spiny-cheek crayfish ranged from 4.8 to $96.6 \mathrm{mg} \mathrm{l}^{-1} \mathrm{~N}^{-\mathrm{NO}_{2}^{-}}$, according to chloride concentration in diluting water in our test.

Very similar results of $48 \mathrm{hLC}_{50}$ found Harris and Coley (1991) in P. leniusculus - $31 \mathrm{mg} \mathrm{l}^{-1} \mathrm{NO}_{2}^{-}$, but in their study the chloride concentration was $0.5 \mathrm{mmol}^{-1} \mathrm{Cl}^{-}$ (17.5 $\mathrm{mg} \mathrm{l}^{-1}$ ) compared to $11 \mathrm{mg} \mathrm{l}^{-1} \mathrm{Cl}^{-}$used in the present study.

Crayfish mortality displayed already after 24-hours exposition as HUEY et al. (1980) and EDDY et al. (1983) reported for fish. High impact of chloride ions to nitrite accumulation in noble crayfish body was presented by JEBERG and JENSEN (1994). We found remarkable differences in nitrite toxicity in low and high level of chloride content in water.

We found positive impact of chlorides also in higher chlorides concentration $\left(400 \mathrm{mg} \mathrm{l}^{-1} \mathrm{Cl}^{-}\right)$than the concentration recommended in Procambarus simulans by BEITINGER and HUEY (1981) (300 $\left.\mathrm{mg} \mathrm{l}^{-1} \mathrm{Cl}^{-}\right)$.

BOYD (1990) in ROUSE et al. (1995) reported in freshwater crustaceans $96 \mathrm{hLC}_{50}$ values in range from 8.5 to $15.4 \mathrm{mg} \mathrm{l}^{-1} \mathrm{~N}-\mathrm{NO}_{2}^{-}$.

Our results are in agreement with this author but comparison is very difficult without information about chloride or other anions concentration in diluting water.

Very interesting is to compare our result with result presented by RUSSO and THURSTON (1977) for rainbow trout. They found linear relationship between nitrite toxicity and chloride concentration in water. They reported that increasing chloride concentration in water by $1 \mathrm{mg} \mathrm{l}^{-1} \mathrm{Cl}^{-}$increase $96 \mathrm{hLC}_{50}$ value by $0.29 \mathrm{mg} \mathrm{l}^{-1} \mathrm{~N}-\mathrm{NO}_{2}^{-}$, that corresponded with our result of $0.225 \mathrm{mg} \mathrm{l}^{-1}$ for the spiny-cheek crayfish.

\section{CONCLUSION}

The $96 \mathrm{hLC}_{50}$ values for nitrite in one-year-old spiny-cheek crayfish ranged from 4.8 to $96.6 \mathrm{mg} \mathrm{l}^{-1} \mathrm{~N}-\mathrm{NO}_{2}^{-}$and were related to the chloride concentration in diluting water in our test. Higher concentration of chlorides in water markedly increased crayfish tolerance to nitrite.

\section{ACKNOWLEDGEMENTS}

This investigation was financially supported by the Grant Agency of Czech Republic project No. 206/03/0532 and by the USB RIFCH NO MSM 6007665809. We thank Přemek Hamr for correcting the English.

\section{REFERENCES}

ATWOOD H.L., FONTENOT Q.C., TOMASSO J.R., ISELY J.J., 2001. Toxicity of nitrite to Nile tilapia: Effect of fish size and environmental chloride. N. Am. J. Aquacult., 63, 1, 49-51.

BEITINGER T.L., HUEY D.W., 1981. Acute toxicity of nitrite to crayfish Procambarus simulans in varied environmental conditions. Environ. pollut. ser. A, vol. 29, 4, 305-311.

COLT J., ARMSTRONG D.A., 1981. Nitrogen toxicity to crustaceans, fish and molluscs. In: ALLEN L.J. and KINNY E.C., (Eds), Proc. of the Bio-Engineering Symposium for Fish Culture pp. 34-47. Fish Culture Section, Northeast Society of Conservation Engineers, Bethesda, MD. 
CRAWFORD R.E., ALLEN G.H., 1977. Seawater inhibition of nitrite toxicity to Chinook salmon. Trans. Am. Fish. Soc., 106, 105-109.

ČSN EN ISO 7346-1, 1999. Jakost vod. Stanovení akutní letální toxicity pro sladkovodní ryby /Brachydanio rerio Hamilton buchanan (Teleostei, Cyprinidae)/. Mater Quality. Evaluation of lethal toxicity for freshwater fish. /Brachydanio rerio Hamilton buchanan (Teleostei, Cyprinidae)/. Part 2. Praha, ČNI 1999, 16 p. (in Czech).

EDDY F.B., KUNZLIK P.A., BATH R.N., 1983. Uptake and loss of nitrite from the blood of rainbow trout, Salmo gairdneri Richardson, and Atlantic salmon, Salmo salar L. in fresh water and in dilute sea water. J. Fish Biol., 23, 105-116.

FULLER S.A., HENNE J.P., CARMICHAEL G.J, TOMASSO J.R., 2003. Toxicity of ammonia and nitrite to the Gila trout. N. Am. J. Aquacult., 65, 2,162-164.

HARRIS R.R., COLEY S., 1991. The effect of nitrite on chloride regulation in the crayfish Pacifastacus leniusculus Dana (Crustacea: Decapoda). J. Comp. Physiol. B, 161, 199-206.

HILMY A.M., EL-DOMIATY N.A., WERSHANA K., 1987. Effect of sodium chloride and calcium chloride on nitrite induced methemoglobinemia in Clarias lazera. Water, Air, Soil Pollut., 33, 57-63.

HUERTAS M., GISBERT E., RODRIGUEZ A., WILLIOT P., CASTELLO-ORVAY F., 2002. Acute exposure of Siberian sturgeon (Acipenser baeri, Brandt) yearlings to nitrite: median-lethal concentration (LCsub (50)) determination, haematological changes and nitrite accumulation in selected tissues. Aquatic Toxicology, 57, 4, 257-266.

HUEY D.W., SIMCO B.A., CRISWELL D.W., 1980. Nitrite-induced methemoglobin formation in channel catfish. Trans. Am. Fish. Soc., 109, 558-562.

JEBERG M.V., JENSEN F.B., 1994. Extracellular and intracellular ionic changes in crayfish Astacus astacus exposed to nitrite at two acclimation temperatures. Aquatic Toxicology, 29, 65-72.

JENSEN F.B., 2003. Nitrite disrupts multiple physiological functions in aquatic animals. Comparative Biochemistry and Physiology - Part A, 135(1), 9-24.

LEWIS W.M., MORRIS D.P., 1986. Toxicity of Nitrite to Fish: A Review. Trans. Am. Fish. Soc., $115,183-195$.

LIU H., AVAULT J.W., MEDLEY P., 1995. Toxicity of ammonia and nitrite to juvenile redclaw crayfish, Cherax quadricarinatus (von Martens). Freshwater Crayfish, 10, 249-255.

LOVE M.R., 1980. The chemical biology of fishes. Academic Press, New York.

MAETZ J., 1971. Fish gills: mechanism of salt transfer in fresh water and sea water. Philosophical Transactions of the Royal Society of London Series B Biological Sciences 262, 209-249.

MEADE M.E., WATTS S.A., 1995. Toxicity of ammonia, nitrite, and nitrate to juvenile Australian crayfish, Cherax quadricarinatus. J. Shellfish Res., vol. 14, no. 2, 341346.

PITTER P., 1999. Hydrochemie. /Hydrochemistry./ VŠCHT, Praha 1999 (in Czech).

POLICAR T., MÁCHOVÁ J., KOZÁK P., 2003. Akutní toxicita volného amoniaku a dusitanů pro račky raka říčního (Astacus astacus L.). /Acute toxicity of ammonia and nitrite for one-year old noble crayfish (Astacus astacus L.)/. In: MÁCHOVÁ, J. (Ed), 2003: Proceeding of 11. conference Toxicity and Biodegradability of Matters and Wastes Important in Water Environment, VÚRH JU Vodňany, Aquachemie Ostrava, 215222 (in Czech with English abstract). 
ROUSE D.B., KASTNER R.J., REDDY K.S., 1995. Toxicity of ammonia and nitrite to hatchling redclaw crayfish, Cherax quadricarinatus. Freshwater Crayfish, 10, 298303.

RUSSO R.C., THURSTON R.V., 1977. The acute toxicity of nitrite to fishes. In: TUBB, R.A. (Ed.), Recent Advances in Fish Toxicity. EPA-600/3-77-085. US Environmental protection Agency, Corvallis, OR, 118-131.

SVOBODOVÁ Z. et al., 1987. Toxikologie vodních živočichů. /Toxicology of Aquatic Animals./ 231 p. (in Czech).

SVOBODOVÁ Z., MÁCHOVÁ J., VESELÝ V., MODRÁ H., SVOBODA M. A KOL., 2003. Veterinární toxikologie - Praktická cvičení. Neterinary toxicology - Practical exercises/, Part I., Brno 2003 (in Czech).

TAVARES L.H.S., BOYD C.E., 2003. Possible effect of sodium chloride treatment on quality of effluents from Alabama channel catfish ponds. J. World Aquacult. Soc., $34,2,217-222$.

WICKINS J.F., 1976. The tolerance of warm water prawns to recirculated water. Aquaculture, 9, 19-37.

WILLIAMS E.M., EDDY F.B., 1986. Chloride uptake in freshwater teleosts and its relationship to nitrite uptake and toxicity. J. Comp. Physiol., B 156: 867-872. 
